\title{
Screening of Antibacterial Activity In Vitro of Eryngium creticum
}

Rim Harfouch ${ }^{1}$, Oussama Mansour ${ }^{2}$, Manal Darwish ${ }^{3}$, Ghenwa Ismail ${ }^{4}$, Rabab Shikh Ali ${ }^{3}$, and Zain Deeb ${ }^{3}$

${ }^{1}$ Department of Microbiology, Faculty of Pharmacy, Al Andalus University

${ }^{2}$ Affiliation not available

${ }^{3}$ Department of Pharmacognosy, Faculty of Pharmacy, Al Andalus University

${ }^{4}$ Department of Pharmaceutics, Faculty of Pharmacy, Al Andalus University

December 21, 2021

\section{Hosted file}

Eryngium creticum rjpt.pdf available at https://authorea.com/users/409829/articles/519643screening-of-antibacterial-activity-in-vitro-of-eryngium-creticum 